\title{
PENGEMBANGAN BAHAN AJAR PERMAINAN FUN OUTBOUND MENCARI HARTA KARUN
}

\author{
Winda Safitri ${ }^{1}$, Sumardi ${ }^{2}$, Heri Yusuf Muslihin ${ }^{3}$ \\ ${ }^{1}$ Program Studi PGPAUD UPI Kampus Tasikmalaya \\ ${ }^{2}$ Program Studi PGPAUD UPI Kampus Tasikmalaya \\ ${ }^{3}$ Program Studi PGPAUD UPI Kampus Tasikmalaya \\ Email: windasaftr@gmail.com
}

(Received: Mei 2020; Accepted: Mei 2020; Published: Juni 2020)

\begin{abstract}
The teaching generally refers to the curriculum that is applied to the school. Teachers are not yet able to develop their own teaching materials. Learning given to children at a young age is focuses on the direction of physical growth and development, language, intellectual, social, emotional, and all intelligence. The problem is that in the learning process it generally reveals only one - way materials by a teacher or teacher center, and the lecture study model. Where the child just sat listening while the teacher explained. Learning is more meaningful if the learning process is carried out experiental learning - that children do tightening in learning. In playing teachers need a manual on a game scenario to be given to learners. The purpose of this study to describe a design for material development a fun outbound game in search of treasure. The method used in this study is educational design research (edr). Data collection techniques interviews, documentation, and expert validation. Data subjects obtained from TK PGRI Lendrasari group $b$ teacher, and validation by the expert validator. Expert validation becomes the product revision. Then the lesson would be a fun outbound book guide for a treasure in the early childhood.
\end{abstract}

Keywords: Teaching Materials, Fun Outbond, Looking for Treasure

\begin{abstract}
Abstrak
Bahan ajar pada umumnya mengacu pada kurikulum yang diterapkan di Sekolah. Guru belum mampu mengembangkan bahan ajar sendiri, guru masih berpacu pada satu bahan ajar yaitu kurikulum 2013. Pembelajaran yang diberikan kepada anak usia dini bukan berorientasi pada akademis saja, melainkan menitik beratkan kepada arah pertumbuhan dan perkembangan fisik, bahasa, intelektual, sosial, emosi serta seluruh kecerdasan. Permasalahan yang terjadi yaitu dalam proses pembelajaran yang dilakukan di dalam kelas, pada umumnya hanya mengungkapkan materi- materi satu arah oleh guru atau teacher center, dan model pembelajaran ceramah. Dimana anak hanya duduk mendengarkan ketika guru menjelaskan. Pembelajaran akan lebih bermakna jika proses pembelajaran dilakukan secara experiental learning yaitu anak melakukan pengindraan dalam belajar. Hampir semua aktivitas yang dilakukan oleh anak adalah bermain. Dalam bermain guru memerlukan buku panduan mengenai skenario permainan yang akan diberikan kepada anak didik. Tujuan penelitian ini untuk mendeskripsikan rancangan desain pengembangan bahan ajar permainan Fun Outbound mencari harta karun. Metode yang digunakan dalam penelitian ini adalah Educational Design Research (EDR). Penelitian ini berbasis desain atau rancangan produk dengan menggunakan pendekatan kualitatif. Teknik pengumpulan data wawancara, dokumentasi, dan validasi ahli. Subjek data diperoleh dari guru kelompok B TK PGRI Lendrasari, dan validasi oleh validator ahli. Hasil validasi ahli menjadi bahan revisi produk. Dengan demikian kesimpulannya Bahan ajar berupa buku panduan permainan Fun Outbound mencari harta karun di PAUD layak digunakan.
\end{abstract}

Keywords: Bahan Ajar, Fun Outbound,mencari harta karun; 


\section{PENDAhUluan}

Melalui upaya pembinaan yang ditujukan kepada anak sejak lahir sampai dengan usia enam tahun dapat membantu pertumbuhan dan perkembangan jasmani dan rohani anak usia dini, serta anak memiliki kesiapan ke jenjang pendidikan selanjutnya. (Permendikbud, 2014: 3) Pendidikan anak usia dini merupakan jenjang bagi anak yang berusia 0 sampai dengan enam tahun, dalam pendidikannya menitikberatkan pada pemberian stimulus untuk perkembangan dan pertumbuhan anak yang optimal agar mampu menolong dirinya untuk menyesuaikan dengan lingkungan atau memiliki kesiapan memasuki jenjang pendidikan selanjutnya.

Pembelajaran yang diberikan kepada anak usia dini bukan berorientasi pada akademis saja, melainkan menitik beratkan kepada arah pertumbuhan dan perkembangan fisik, bahasa, intelektual, sosial, emosi serta seluruh kecerdasan. Menurut Yus, A, 2011, hlm 13. "Guru dapat merancang suatu pembelajaran yang dengan memberikan pengalamanpengalaman yang dapat merangsang pertumbuhan dan perkembangan anak untuk mengoptimalkan seluruh aspek perkembangan".

Permasalahan di Pendidikan Anak Usia Dini yang terjadi pada umumnya yaitu, salah satunya dalam proses pembelajaran yang dilakukan di dalam kelas, pada umumnya hanya mengungkapkan materimateri satu arah oleh guru atau teacher center, dan model pembelajaran ceramah yang dimana anak hanya duduk mendengarkan ketika guru menjelaskan. Adapun Pembelajaran akan lebih berma kna jika proses pembelajaran dilakukan secara experiental learning yaitu anak melakukan pengindraan dalam belajar, anak merasakan langsung sesuatu hal dengan alat indranya. Di samping itu pembelajaran yang berada di luar ruang kelas bisa meningkatkan mood anak, mental anak akan lebih meningkat lagi jika dibandingkan belajar di dalam Kelas, anak akan merasa senang karena terbawa oleh suasana lingkungan di luar ruangan yang lebih terbuka. Kemudian sesuatu hal yang berkesan bagi anak akan tersimpan lama dalam ingatan atau memori anak. Memori anak usia dini akan membekas lama jika pengalaman yang dialaminya berkesan, dapat diungkapkan bahwa anak dengan mendapatkan pengalaman secara langsung akan lebih berkesan lama dalam ingatan dibandingan dengan tidak melakukan pengalaman secara langsung.

Dunia anak-anak diseluruh dunia sesungguhnya adalah dunia bermain. Orang-orang dewasa dan lingkungan sekitar merekalah yang mempunyai kewajiban untuk menyediakan dunia yang penuh dengan permainan bagi mereka. Merujuk pada hal tersebut, bermain merupakan sesuatu yang menyenangkan bagi anak, ia akan berlama- lama dalam dalam suatu permainan. Tapi pada saat yang lain juga ia bermain hanya sebentar saja. Anak dapat menggunakan alat apa saja atau segala sesuatu yang ada di dekatnya untuk bermain, misalnya dengan jari-jari tangannya. (Yus, A. 2011, hlm. 20)

Hampir semua aktivitas yang dilakukan oleh anak adalah bermain. Dalam bermain anak tidak merasakan adanya paksaan, baginya segala sesuatu yang ia kerjakan adalah itu yang menjadi kesenangannya. Dengan bermain seluruh aspek perkembangan anak dapat berkembang, tanpa disadari, dalam bermain anak melakukan pengamatan, membandingkan, mengukur, bereksplorasi, bereksperimen, berkhayal dan masih banyak lagi yang dapat dilakukan oleh anak. Hal ini sering terjadi tanpa disadari oleh orang dewasa, bahwa ia memiliki kemampuan baru setelah ia bermain sendiri, maka dari itu bermain perlu ada arahan dari orang dewasa.

Merujuk pada hal tersebut, dalam Standar Tingkat Pencapaian Perkembangan Anak (STPPA) disebutkan Aspek Perkembangan Sosial-emosional anak usai dini ada tiga yaitu, kesadaran diri, rasa tanggung jawab untuk diri dan orang lain dan Perilaku Prososial. Perilaku prososial diantaranya yaitu: mampu bermain dengan teman sebaya, memahami perasaan, merespon, berbagi, serta menghargai hak dan pendapat orang lain; bersikap kooperatif, toleran, dan berperilaku sopan.

Kenapa muncul permasalahan interaksi sosial anak pada usia lima sampai enam tahun diantaranya yaitu; "biasanya anak memiliki teman baik, meskipun dalam jangka waktu yang pendek, anak sering bertengkar meskipun dalam waktu yang singkat, anak belum mau untuk berbagi dan mengambil giliran, ingin menjadi yang nomor satu, dan lebih posesif terhadap barang-barang kepunyaannya" ( Sujiono, YN, 2013, hlm. 66).

Sejalan dengan hal tersebut, Pembelajaran anak usia dini tidak hanya dilakukan di dalam ruangan saja, juga bisa 
dilakukan di alam terbuka dengan metode Outbound (Outward Bound). Sedangkan di Lembaga-lembaga yang peneliti temui kebanyakan pembelajaran hanya dilakukan di dalam Kelas saja, pembelajaran berpusat pada guru dan penyampaian-penyampaian teori saja. Outbound merupakan suatu metode pembelajaran experiental learning, metode outbound lebih efektif dalam pemahaman terhadap suatu konsep dan membangun perilaku karakter individu. Dalam pembentukan karakter ini akan menjadikan individu yang lebih baik lagi. (Buchori, S, dkk. 2016, hlm 14)

Penelitian tentang Outbound sudah banyak dilakukan antara lain oleh : Imania, KAN (2015), Wijayanto, S (2016), Febriana, AK (2017), Rizal, AYC. (2017), Wahjoedi, dkk. ( 2017), Fauziyah, N (2018), Sintia, N(2018). Dan penelitian tentang Interakasi sosial antara lain: Pilarningtyas, RS, (2016), Putri, BM (2015), Sahid, OSZ (2017). Penelitian tersebut lebih banyak membahas mengenai outbound tentang motorik kasar anak, kepemimpinan anak, motivasi belajar anak, kerjasama anak. Kebanyakan juga penelitian dilakukan di SD, SMP, SMA, dan karyawan. Adapun penelitian ini akan mengangkat fun outbound untuk meningkatkan interaksi sosial anak usia dini, usia lima sampai dengan enam tahun.

Fun Outbound merupakan aktivitas di luar ruangan yang berbasis alam, biasanya disajikan dalam berbagai bentuk permainan yang betujuan sebagai hiburan maupun mengasah keterampilan juga bermanfaat untuk meningkatkan berbagai hal seperti kerjasama, kepemimpinan, interaksi sosial, dan lain-lain. Biasanya aktivitas fun outbound dilaksanakan oleh suatu lembaga sekolah, family gethring, dan, karyawan suatu pabrik. Outbound dirasa cocok untuk meningkatkan aspek perkembangan anak usia dini, khususnya dalam meningkatkan interaksi sosial anak usia lima sampai enam tahun, karena kegiatannya dilakukan secara langsung oleh anak atau experiental learning. Jadi anak bisa mendapatkan pengalaman yang lebih bermakna dari pada proses pembelajaran yang hanya duduk mendengarkan guru menjelaskan materi.

Hal inilah yang menjadi dasar dalam penelitian kali ini. Peneliti melakukan penelitian dan pengembangan mengenai Permainan dengan judul "Pengembangan Bahan Ajar Permainan Fun Outbound Mencari Harta Karun”.

\section{TINJAUAN PUSTAKA}

\section{a. Konsep Dasar Bahan Ajar}

Bahan ajar dapat diartikan sebagai seperangkat fakta, konsep, prinsip, prosedur, dan atau generalisasi yang dirancang secara khusus untuk memudahkan pengajaran. Secara lebih sempit bahan ajar juga biasanya disebut sebagai materi pembelajaran". ( Abidin, Y. 2016, hlm. 263). Sejalan dengan Arsanti, M. (2018, hlm. 72). Menyatakan bahwa bahan ajar memiliki peran penting dalam keefektikan pembelajaran di Sekolah. Dalam proses perencanaan pembelajaran guru bertugas untuk menyiapkan bahan ajar yang dapat menunjang proses pembelajaran, sehingga dapat membantu siswa dalam mencapai tujuan pembelajaran secara optimal. Bahan ajar tersebut dapat berupa tertulis seperti hand out, buku, modul, lembar kerja anak, brosur, leaflet, wallchart, maupun bahan tidak tertulis seperti video/ film, VCD, radio, kaset, CD interaktif berbasis komputer dan internet.

Dengan demikian, dapat disimpulkan bahwa bahan ajar merupakan hal yang sangat penting untuk dikembangkan. Sebagai upaya untuk meningkatkan kualitas pembelajaran di Sekolah karena memiliki peran baik bagi guru maupun siswa.

\section{b. Fungsi Bahan Ajar}

Menurut Abidin, Y. (2016, hlm. 263) "Bahan ajar memiliki fungsi penting bagi pembelajaran. Beberapa fungsi bahan ajar tersebut adalah sebagai berikut".

1) Pedoman bagi guru yang akan mengarahkan semua aktivitasnya dalam proses pembelajaran, sekaligus merupakan substansi kompetensi yang seharusnya diajarkan kepada siswa.

2) bagi siswa yang akan mengarahkan semua aktivitasnya dalam proses pembelajaran, sekaligus merupakan substansi kompetensi yang seharusnya dipelajari atau dikuasainya.

3) Alat evaluasi pencapaian atau penguasaan hasil pembelajaran.

\section{c. Fun Outbound}

"Pendidikan melalui kegiatan alam terbuka mulai dilakukan tahun 1821 disaat didirikannya Round Hill School. Secara sistematik pendidikan melalui kegiatan outbound dimulai tahun 1941 di Inggris." (Ancok, D. 2002, hlm. 1-2). Outbound merupakan kegiatan berupa permainan yang dilakuakan di ruangan terbuka dengan memberikan pengelaman langsung kepada 
anak melalui tantangan, petualangan dan rekreasi. ( Yeni, RA. 2019, hlm 163). Kemudian menurut Susanta, A. (2010, hlm 11) Pembagian dan Persiapan Outbound dibagi menjadi dua:

1) Real Outbound, yaitu peserta memerlukan ketahanan dan tantangan fisik besar untuk menjalani petualangan yang mendebarkan dan penuh tantangan.

2) Fun Outbound/ Semi Outbound, yaitu kegiatan di alam terbuka yang hanya melibatkan permainan ringan, menyenangkan, dan beresiko kecil atau sedang, namun tetap bermanfaat bagi pengembangan peserta, khususnya dari sisi sosial/ interaksi dengan sesama.

Dari pembagian outbound di atas peneliti memilih Fun Outbound untuk dikembangkan di Pendidikan Anak Usia dini. Karena Fun Outbound atau semi outbound adalah salah satu kegiatan yang mana pesertanya terlibat dalam sebuah kontes dengan peserta lainnya atau bisa disebut Outbound Fun Games.

Mayoritas outbound memang dilakukan di ruang terbuka, karena metode yang digunakan pada outbound adalah experiental learning (belajar dari pengalaman). Metode ini akan lebih efektif jika peserta langsung melakukan praktik. Pasalnya, retensi (masa daya ingat) akan lebih panjang dibandingkan jika peserta sekedar belajar teori di dalam kelas. Sempitnya ruang kelas juga membatasi aktivitas anak usia dini.

Pendekatan dengan aktivitas outdoor dianggap lebih dapat mengakomodasi metode pembelajaran anak usia dini (early childhood education). Anak usia lima sampai enam tahun kurang menyukai suasana formal karena akan menghambat proses berfikir dan ruang geraknya. Sebaliknya jika anak belajar dalam suasana bebas, terbuka, dan tidak kaku maka anak akan sangat menyukainya.

\section{d. Permainan Mencari Harta Karun}

Permainan berburu harta karun atau yang biasa disebut dengan treasure hunt adalah jenis permainan yang populer di anak-anak dan remaja. Tetapi jarang ditemukan di Sekolah yang peneliti temui, permainan ini cocok dilakukan kapan saja dengan keadaan enjoy, fun dan refresh. Perburuan bisa menjadi sangat menyenangkan jika ada banyak harta karun, juga supaya setiap orang menemukan banyak harta karun. Mengalami "iri harta karun", rasa iri yang dirasakan ketika melihat keranjang orang lain penuh bukanlah pengalaman yang menyenangkan".

Permainan ini adalah perburuan harta karun yang menyenangkan yang menunjukkan benda-benda sesuai tema di Sekolah. Jenis aspek yang dikembangkan adalah Interasksi verbal, interaksi fisik, interaksi emosional anak.

Peralatan yang dibutuhkan:

1) Benda (harta karun) yang disesuaikan dengan tema di PAUD dan disesuaikan dengan usia anak.

2) Keranjang atau wadah

Instruksi:

Sembunyikan benda dimana saja, di area outbound. Letakkan beberapa di daerah yang jelas seperti di area permainan outdoor, dan sembunyikan beberapa di daerah yang lebih sulit seperti di semaksemak atau di lingkungan alam sekitar lainnya. Permainan ini bertujuan supaya anak mau bekerja sama saling berinteraksi anak dengan kelompoknya untuk mencari harta karun dan membaginya kemudian nanti di sebutkan dan di jelaskan benda (harta karun) hasil temuannya itu kepada guru dan teman-teman lainnya.

Hal yang dipelajari dalam permainan ini melatih kemampuan mengobservasi anak yaitu anak mengamati lingkungan alam secara langsung dan tentunya bagi anak pencarian harta karun ini akan berkesan, juga secara tidak langsung anak mau berinteraksi dengan temannya yaitu berbaur dalam kelompok (team) untuk menyelesaikan tujuan yang sama. Mereka merasa semangat karena mereka adalah bagian dari kelompok.

\section{METODE}

Penelitian ini menggunakan metode penelitian Educational Based Research atau disingkat menjadi EDR, penelitian ini berbasis desain atau rancangan produk dengan menggunakan pendekatan kualitatif. Proses pengembangan perangkat pembelajaran berupa Desain permainan ini mengacu pada model pengembangan Educational Design Research karya McKenney \& Reeves. terdapat tiga tahapan dalam model penelitian menurut McKenney dan Reeves, yaitu:

1) Tahap Exploration andAnalysis

Pada tahap exploration and analysis, peneliti melakukan analisis masalah serta mengeksplorasi masalah melalui studi pendahuluan ke Sekolah dengan observasi, melakukan wawancara terhadap fokus penelitian. Aspek yang diteliti adalah permainan yang dilakukan oleh guru di 
Kelas dan di luar Kelas. Peneliti juga mengumpulkan informasi dari guru mengenai hal apa saja yang menjadi penghambat serta kesulitan yang dialami oleh guru ketika membuat skenario permainan di Kelas maupun di Luar Kelas. Pada tahap ini juga, peneliti melakukan kajian literatur. Yaitu dengan cara mempelajari penelitian-penelitian sebelumnya yang relevan dengan variabel penelitian peneliti, membaca sumbersumber terkait dengan fokus penelitian peneliti.

Tahap exploration and analysis ini berfungsi untuk mencari dan menganalisis permasalahan yang akan diangkat dalam penelitian di kelas B TK PGRI Lendrasari, Kecamatan Cikoneng Kabupaten Ciamis. Pengambilan data pada penelitian ini dilakukan dengan dua tahap yaitu studi literatur dan studi lapangan. Studi literatur yaitu berupa kajian dari buku, jurnal dan penelitian terdahulu. Sedangkan studi lapangan yaitu berupa observasi dan wawancara kepada guru kelas B TK PGRI Lendrasari, Kecamatan Cikoneng Kabupaten Ciamis.

Adapun permasalahan dalam penelitian ini adalah tidak dilaksanakannya uji coba untuk melaksanakan pembelajaran pada permaianan Fun Outbound mencari harta karun untuk anak usia lima sampai enam tahun. Dalam memperoleh data yang cukup untuk menjawab permasalahan tersebut, maka dilakukan wawancara kepada guru kelompok B TK PGRI Lendrasari (Tati S.Pd) sehingga diperoleh data yang sesuai dengan keadaan di lapangan.

Setelah wawancara dilaksanakan, semua kebutuhan terkait pelaksanaan pembelajaran permaianan Fun Outbound mencari harta karun untuk anak usia dini peneliti mengembangkan skenario permainan Fun Outbound. Dalam permainan Fun Outbound mencari harta karun, anak belajar dari pengalamanya mengenai banyak hal. Anak juga dapat menggali pengetahuannya sendiri dalam kegiatan permainan ini, terciptanya interaksi sosial antar sesama teman menjadi salah satu acuan tugas dalam perkembangan sosial emosional anak usia dini. Dalam hal ini dimaksudkan agar anak usia dini memiliki keterampilan menyesuaikan diri dengan lingkungan untuk bekal memasuki jenjang pendidikan berikutnya.

\section{1) Tahap Design and Construction}

Pada tahap design and construction ini, peneliti menyusun rancangan desain produk yang dikembangkan. Adapaun rancangan produk ini berdasarkan pada teori-teori mengenai desain yang akan dibuat, dan permasalahan yang dianalisis. Sehingga produk yang dihasilkan dapat memecahkan permasalahan tersebut. Solusi yang ditawarkan peneliti yaitu melakukan perancangan untuk pengembangkan produk berupa skenario permainan Fun Outbound mencari harta karun, berdasarkan analisis kebutuhan konteks masalah yang telah dilakukan peneliti untuk mengembangkan bahan ajar permainan Fun Outbound mencari harta karun untuk anak usia dini. Setelah produk selesai dibuat oleh peneliti, selanjutnya dilakukan uji validasi oleh validator ahli yaitu dosen ahli yang sesuai di bidangnya, dan ahli pedagogik oleh guru kelompok B.

\section{2) Tahap Evaluation and Reflection}

Tahap ketiga ini secara umum adalah tahap evaluasi dan refleksi dengan melakukan uji coba produk dan menilai produk yang dikembangkan, atau evaluasi produk. Pada tahap evaluasi dan refleksi ini tidak terlaksana karena adanya pandemi covid-19 yang menyebabkan anak belajar dari rumah.

Peneliti hanya melakukan validasi ahli. Data yang diperoleh adalah berupa data yang dikumpulkan yaitu masukan dari para ahli, peninjauan data masukan dari para ahli tersebut dilaksanakan sebagai tahap akhir dalam penelitian. Masukan dari para ahli juga untuk memodifikasi dan perbaikan akhir produk, data yang telah didapatkan dapat digunakan untuk memecahkan masalah yang menjadi fokus penelitian yang diangkat oleh peneliti.

Pada pelaksanaan pengumpulan data, pengambilan subjek sumber data penelitian dilaksanakan melalui tahap analisis masalah melalui studi pendahuluan di TK PGRI Lendrasari Cikoneng. Sedangkan tahap uji coba tidak terlaksana karena adanya pandemi covid- 19 yang menyebabkan anak Study From Home.

Jenis data yang dibutuhkan dalam penelitian ini adalah data yang berkaitan dengan pengembangan bahan ajar permainan Fun Outbound Mencari Harta Karun untuk anak usia dini, diantaranya yaitu:

1) Rancangan skenario permainan

2) Hasil validasi Ahli

Menurut Sugiyono (2015, hlm 308) "Teknik pengumpulan data merupakan langkah yang paling utama dalam penelitian, tujuan utama dari penelitian 
adalah mendapatkan data. Bila dihilat dari segi cara atau teknik pengumpulan data, maka teknik pengumpulan data dapat dilakukan dengan observasi, interview, kuesioner, dokumentasi, dan gabungan keempatnya".

Teknik pengumpulan data yang digunakan dalam penelitian ini yaitu:

1) Wawancara

Menurut Creswell, JW. (2017, hlm 267) "dalam wawancara kualitatif, peneliti dapat melakukan face-to-face interview (wawancara berhadap-hadapan) dengan partisipan, mewawancarai mereka dengan telepon, atau terlibat dalam focus group interview (interview dalam kelompok tertentu) yang terdiri dari enam sampai delapan partisipan perkelompok". Wawancara dilakukan kepada guru kelompok B yaitu, Tati S.Pd TK PGRI Lendrasari Cikoneng Kabupaten Ciamis.

\section{2) Observasi}

"Observasi kualitatif merupakan observasi yang didalamnya peneliti langsung turun ke lapangan untuk mengamati perilaku dan aktivitas individuindividu di lokasi penelitian. Dalam pengamatan ini, peneliti merekam/ mencatat baik dengan cara terstruktur maupun semi terstruktur aktivitas-aktivitas dalam lokasi penelitian". (Creswell, JW. 2017, hlm 267)

Jenis observasi yang dilaksanakan adalah observasi non partisipan, yaitu peneliti tidak ikut serta dalam kegiatan pembelajaran. Tetapi peneliti hanya mengobservasi saat dilaksanakannya pembelajaran. Observasi hanya dilaksanakan dalam satu tahap, yaitu pada saat studi pendahuluan dalam melihat permainan atau pembelajaran di TK PGRI Lendrasari.

3) Hasil Exspert Judgement (Validasi dari ahli)

Penilaian dari para ahli ini penting dilakukan karena untuk memvalidasi produk yang dikembangkan, dalam penelitian ini para ahli meninjau skenario permainan Fun Outbound mencari harta karun yang telah dirancang oleh peneliti dengan melihat kesesuaian produk dengan permasalahan yang diangkat, kelayakan produk, kepraktisan produk juga keterpakaian produk oleh guru di Lapangan.

\section{HASIL DAN PEMBAHASAN}

Pengembangan bahan ajar permainan Fun Outbound untuk anak usia dini ini menggunakan penelitian berbasis pengembangan yang dinamakan Educational Design Research (EDR) dengan menggunakan analisis data kualitatif. Model EDR terdiri dari tiga tahap, yaitu Exploration and Analysis, Design and Contruction, dan Evaluation and Reflektion, ketiga tahap tersebut dilakukan secara siklikal dimulai saat peneliti mengidentifikasi dan menganalisis masalah di lapangan, kemudian peneliti merancang bentuk desain permainan sebagai solusi dari permasalahan yang ditemukan, setelah itu dilakukan validasi ahli skenario permainan Fun Outbound untuk mengetahui kepraktisan dan keterpakaian dari produk yang yang dikembangkan. Pengembangan desain permainan ini berfokus pada pengembangan bahan ajar berupa buku panduan skenario permainan, sehingga produk yang dikembangkan adalah skenario permaian Fun Outbound mencari harta karun untuk anak usia dini. Faktor penghambat dalam pembelajaran Fun Outbound yaitu guru kurang kreatif dalam merancang permainan di outdoor, sehingga kurang optimalnya pembelajaran Fun Outbound di area lingkungan Sekolah. Pengembangan desain permainan Fun Outbound mencari harta karun untuk anak usia dini dilaksanakan dalam tiga tahap, diantaranya:

\section{a. Exploration and Analysis}

Identifikasi dan analisis masalah pada penelitian ini dilakukan dengan cara studi literatur dan studi pendahuluan di Kelompok B TK PGRI Lendrasari. Tahap eksplorasi dan analisis pada penelitian ini adalah melakukan studi literatur dan studi lapangan untuk mengidentifikasi masalah yang ada.

\section{1) Studi Literatur}

Peneliti melakukan studi literatur untuk menemukan hasil kajian teori terhadap keadaan pembelajaran di Lapangan yaitu masih berpusat pada guru (teacher center) dengan metode ceramah atau satu arah yaitu guru memberikan materi-materi terhadap anak, sedangkan anak duduk mendengarkan saja. Experiental learning juga kurang dikembangkan oleh guru ketika belajar di Kelas maupun di luar Kelas. Hal ini sejalan dengan pernyataan Natalina, D dan Gandana, G. (2017, hlm. 211) bahwa "Proses penyampaian informasi untuk anak usia dini dapat dilakukan melalui metode ceramah, tanya jawab, eksperimen, observasi, inquiry (mencari sendiri), redundancy (mengulangulang pesan), dan sebagainya”. Metode 
dipilih berdasarkan karakteristik yang tepat sesuai dengan pertimbangan yang dianalisis di Sekolah.

Peneliti juga melakukan studi literatur terhadap kurikulum, kurikulum yang digunakan di TK PGRI Lendrasari adalah kurikulum 2013.

Dalam studi literatur ini, peneliti menyimpulkan bahwa pada umumnya fakta di beberapa sekolah pembelajaran di dalam kelas masih menggunakan metode pembelajaran konvensional yaitu metode ceramah yang paling dominan. Sejalan dengan Peraturan Menteri Pendidikan dan Kebudayaan Republik Indonesia Nomor 81A Tahun 2013 tentang Implementasi Kurikulum, pada Lampiran IV (Pedoman Umum Pembelajaran) tertera bahwa:

"Untuk mencapai kualitas yang telah dirancang dalam dokumen kurikulum, kegiatan pembelajaran perlu menggunakan prinsip yang berpusat pada peserta didik, mengembangkan kreativitas peserta didik, menciptakan kondisi menyenangkan dan menantang, bermuatan nilai, etika, estetika, logika, dan kinestetika dan menyediakan pengalaman belajar yang beragam melalui penerapan berbagai strategi dan metode pembelajaran yang menyenangkan, kontekstual, efektif, efisien, dan bermakna."

\section{2) Studi Pendahuluan}

Hasil dari studi pendahuluan yang dilakukan peneliti yaitu dapat disimpulkan bahwa pembelajaran di Sekolah saat ini belum banyak mengembangkan bahan ajar berupa buku panduan skenario permainan. Pada permainan Fun Outbound guru masih suka mengajak anak pergi ke tempat wisata seperti hutan pinus, padahal di dalam ruangan kelas dan di halaman Kelas juga bisa dilakukan permainan mencari harta karun, karena esensinya Outbound. Interaksi sosial adalah salah satu cara untuk mengetahui kemampuan anak dalam bidang perkembangan sosial, guru kurang mengembangkan kemampuan interaksi sosial anak di Sekolah dengan variasi permainan-permainan. Peneliti juga melakukan studi lapangan dengan mewawancarai guru Kelompok B di TK PGRI Lendrasari terhadap perancangan buku panduan skenario permainan Fun Outbound mencari harta karun. Subjek identifikasi masalah dalam penelitian ini adalah TK PGRI Lendrasari karena sekolah tersebut menerapkan Kurikulum 2013.

Berikut adalah hasil identifikasi dari sekolah yang dilakukan peneliti:

Lembaga : TK PGRI Lendrasari
Kelas : B

Berdasarkan hasil wawancara yang dilakukan kepada ibu Tati, S.Pd., informasi yang didapatkan peneliti bahwa bahan ajar yang guru ketahui adalah materi atau kumpulan materi yang akan diberikan kepada anak didik. Bahan ajar yang digunakan di TK PGRI Lendrasari yaitu kurikulum 2013, yang mengembangkan enam bidang pengembangan yaitu nilai agama moral, fisik motorik, kognitif, bahasa, seni, dan sosial emosional. Selama ini guru belum mampu untuk membuat panduan bahan ajar tapi disini guru hanya menggunakan pedoman yang sudah ada, yaitu dari kurikulum 2013. Skenario permainan adalah perencanaan kegiatan yang akan dilaksanakan dengan anak didik. Sebelum melaksanakan permainan yang pertama dipersiapkan adalah pedoman, alat, bahan, tempat, anak didik yang akan melakukan permainan, dan waktu yang sudah disetting. Biasanya permainan dilaksanakan pada kegiatan inti atau dikegiatan awal pertemuan. Untuk permainan Outbound sudah sering dilaksanakan tetapi untuk permainan mencari harta karun belum pernah. Outbound biasa dilaksanakan di halaman Sekolah, di halaman kantor desa Sindangsari, kemudian ketika anak-anak diajak jalan-jalan mengenal lingkungan, atau di suatu tempat yang memungkinkan untuk melakukan Fun Outbound. Guru mempersiapkan skenario permainan tersebut tapi bentuknya secara klasikal, tidak tertulis. Kendala guru dalam mengembangkan permainan Fun Outbound yaitu dari alat yang terbatas, kemudian dari anak sendiri, karena tidak semua anak mau mengikuti permaian dengan maksimal. Adapun cara guru mengukur kemampuan sosial anak dengan melihat apakah anak sudah mampu mengikuti permainan, mampu kerjasama dengan temannya untuk bersosialisasi dalam permainan itu, karena tidak semua anak tidak mau mengikuti. Masih terdapat anak yang belum bisa melakukan interaksi sosial, tetapi hanya sebagian kecil saja. Alasannya dikarenakan anak tidak tertarik dengan permainan, malah senang dengan permainan yang lain. Penting sekali meningkatkan interaksi sosial karena berinteraksi itu untuk memupuk rasa sosial anak, melatih kerjasama anak, sosialisasi dengan antar teman. Usaha guru untuk meningkatkan interaksi sosial anak yaitu dengan cara pendekatan kepada anak secara individual, diajak untuk terlibat dalam permainan, 
dirangsang, diberi motivasi, diberi reward, atau apa saja supaya anak mau terjun langsung dalam permainan, dan memberikan alat permainan yang menarik. Bagus sekali jika permainan Fun Outbound mencari harta karun untuk memfasilitasi interaksi sosial anak usia dini dikembangkan, karena kebetulan di sekolah ini belum pernah dilaksanakan permainan mencari harta karun. Harapan guru permainan ini bisa di uji cobakan di TK PGRI Lendrasari, pasti anak-anak senang karena permainan ini menantang, mencari sesuatu dengan berkelompok itu bisa melatih interaksi sosial anak.

\section{b. Design and Contruction}

Pada tahap kedua ini, peneliti mulai menyusun rancangan desain produk yang dihasilkan dan dikembangkan. Perancangan produk ini berdasarkan dari studi literatur dan studi pendahuluan mengenai desain yang akan dibuat untuk mengatasi permasalahan yang dianalisis oleh peneliti. Dalam langkah ini peneliti merancang buku panduan skenario permainan Fun Outbound mencari harta karun untuk anak usia dini. Tahap mengembangkan desain permainan ini difokuskan pada beberapa kegiatan, yaitu: Membuat prinsip desain, menentukan KI (Kompetensi Inti) dan KD (Kompetensi Dasar), menentukan indikator dan tujuan pembelajaran, menentukan materi ajar, dan merancang prototype awal desain permainan.

\section{1) Analisis Rancangan Desain Produk}

Hasil Analisis Program Pengembangan, Kompetensi Inti, Kompetensi Dasar, Indikator Pencapaian, Model Permainan, Tujuan Permainan, Materi, dan Media

\begin{tabular}{ll}
\hline $\begin{array}{l}\text { Program } \\
\text { Pengem } \\
\text { bangan }\end{array}$ & $\begin{array}{l}\text { Nilai Moral dan Agama } \\
\text { Tuhan semesta }\end{array}$ \\
& $\begin{array}{l}\text { Fisik Motorik } \\
\text { 1. Mengkoordinasikan motorik } \\
\text { halus }\end{array}$ \\
& $\frac{\text { Kognitif }}{\text { 1. Berani mencoba hal baru }}$ \\
& $\begin{array}{l}\text { Sosial Emosional } \\
\text { 1. Menyampaikan pendapat }\end{array}$ \\
& $\begin{array}{l}\text { 2. Mendengarkan temannya } \\
\text { berbicara }\end{array}$ \\
& $\begin{array}{l}\text { 3. Gotong royong/ tolong } \\
\text { menolong }\end{array}$ \\
& 4. Mau bermain dengan teman \\
& $\begin{array}{l}\text { Bahasa Bercerita } \\
\text { pengalaman anak }\end{array}$ \\
\hline
\end{tabular}

2. Ekspresi wajah (senang, marah, sedih) $\underline{\text { KI 2: }}$

Kompet Memiliki perilaku hidup sehat, ensi Inti rasa ingin tahu, kreatif dan estetis, percaya diri, disiplin, mandiri, peduli, mampu bekerjasama, mampu menyesuaikan diri, jujur, rendah hati dan santun dalam berinteraksi dengan keluarga, pendidik dan teman.

KI 3:

Mengenali diri, keluarga, teman, pendidik, lingkungan sekitar, teknologi, seni, dan budaya di Rumah, tempat bermain, dan satuan PAUD dengan cara: mengamati dengan indra (melihat, mendengar, menghidu, merasa, meraba); menanya; mengumpulkan informasi; menalar, dan mengomunikasikan melalui kegiatan bermain.

KI 4:

Menunjukkan yang diketahui, dirasakan, dibutuhkan, dan dipikirkan melalui bahasa, musik, gerakan, dan karya secara produktif dan kreatif, serta mencerminkan, perilaku anak berakhlak mulia.

\section{KD 2.5:}

Kompet Memiliki perilaku yang ensi mencerminkan sikap percaya Dasar diri

\section{KD 2.7:}

Memiliki perilaku yang mencerminkan sikap sabar (mau menunggu giliran, mau mendengar ketika orang lain berbicara) untuk melatih kedisiplinan.

KD 2.10:

Memiliki perilaku yang mencerminkan sikap kerjasama KD 3.8:

Mengenal lingkungan alam (hewan, tanaman, cuaca, tanah, air, batu-batuan, dll)

KD 3.11:

Memahami bahasa ekspresif (mengungkapkan bahasa verbal dan non verbal)

KD 4.3:

Menggunakan anggota tubuh untuk pengembangan motorik kasar dan halus 


\begin{tabular}{ll}
\hline & Kelompok \\
Model & 1. Berorientasi pada anak \\
Permain & 2. Berinteraksi langsung \\
an & $\begin{array}{l}\text { dengan alam } \\
\text { 3. Mendukung experiental } \\
\end{array}$ \\
& learning, dan interaksi sosial \\
\hline
\end{tabular}

Tujuan 1. Anak dapat belajar di luar Permain ruangan kelas (mengenal an lingkungan alam sekitar lingkungan Sekolah)

2. Kebahagiaan / mood anak dapat meningkat melalui experiental learning

3. Anak dapat berinteraksi dengan teman dan guru

Materi Permainan Fun Outbound anak usia dini

1. Memfasilitasi anak dalam memperoleh pengalaman tentang permainan yang dilakukan

2. Menugaskan anak untuk mengamati, mencari tahu, melakukan hal baru dan memecahkan masalah.

3. Membimbing agar anak memiliki hasrat ingin tahu, mau bekerja sama, mau berusaha menyelesaikan tugas dan menyesuaikan dengan lingkungan.

4. Kemampuan Interaksi Verbal kemampuan berinteraksi atau mengomunikasikan dengan menggunakan bahasa atau kata-kata.

5. Kemampuan Interaksi Fisik kemampuan berinteraksi atau mengomunikasikan dengan menggunakan bahasa tubuh atau kontak fisik

6. Kemampuan Interaksi Emosional kemampuan berinteraksi atau mengomunikasikan dengan menggunakan perasaan atau ekspresi.

Sumber Skenario Permainan Fun belajar Outbound Mencari Harta Karun

\section{2) Hasil dan Analisis Produk}

Validasi produk skenario permainan Fun Outbound mencari harta karun dilakukan oleh dosen pembimbing yang ahli dalam produk yang dikembangkan oleh peneliti, juga oleh ahli pedagogik yaitu guru Kelompok B. Validator mengkoreksi terhadap buku panduan skenario permainan terhadap hal yang kurang tepat. Berikut ini adalah validator yang memvalidasi produk skenario permainan Fun Outbound mencari harta karun untuk anak usia dini.

\begin{tabular}{|c|c|}
\hline \multicolumn{2}{|c|}{ Daftar Nama Validator } \\
\hline Nama & Keterangan \\
\hline $\begin{array}{l}\text { Drs. H. Sumardi, } \\
\text { M.Pd. }\end{array}$ & $\begin{array}{ll}\text { Dosen } & \text { UPI } \\
\text { Kampus } & \\
\text { Tasikmalaya } & \\
\text { (Pembimbing } & 1)\end{array}$ \\
\hline $\begin{array}{l}\text { Dr. H. Heri Yusuf } \\
\text { Muslihin, M.Pd }\end{array}$ & $\begin{array}{ll}\text { Dosen } & \text { UPI } \\
\text { Kampus } & \\
\text { Tasikmalaya } & \\
\text { (Pembimbing } & \text { 2) }\end{array}$ \\
\hline Tati, S.Pd & $\begin{array}{l}\text { Guru Kelompok B } \\
\text { TK } \quad \text { PGRI } \\
\text { Lendrasari }\end{array}$ \\
\hline
\end{tabular}

Validasi Produk dilaksanakan di tempat dan waktu, sebagai berikut:

1) Validasi oleh ahli materi Interaksi Sosial

Nama Validator :Drs. H. Sumardi, M.Pd.

Hari, tanggal : Jumat, 17 Juli 2020

Saran : Hasil valilasi produk secara umum sudah memenuhi aspek yang terdapat pada lembar validasi ahli. Terdapat arahan dan rekomendasi yang menyarankan untuk menambahkan desain atau latar belakang pada pada buku supaya tidak terlalu polos. Untuk keseluruhan tidak ada komentar lainnya.

2) Validasi oleh ahli materi desain Pemainan

Nama Validator : Dr. H. Heri Yusuf

Muslihin, M.Pd

Hari, tanggal : Rabu, 15 Juli 2020

Saran : Hasil validasi produk secara umum sudah memenuhi seluruh aspek yang terdapat pada lembar validasi ahli. Terdapat arahan dan rekomendasi yang menyarankan untuk melengkapi langkah-langkah dan cara-cara bermain pada buku, menyertakan contoh ilustrasi dalam skenario permainan tersebut. Kemudian menyesuaikan jarak tulisan pada buku agar nyaman di baca oleh guru, dan mengubah ukuran buku menjadi lebih kecil agar menarik.

3) Validasi oleh ahli Pedagogik

Nama Validator : Tati, S.Pd

Hari, tanggal : Selasa, 21 Juli 2020

Saran : Hasil validasi secara umum sudah memenuhi seluruh aspek yang terdapat pada lembar validasi ahli. Terdapat beberpa arahan dan rekomendasi 
diantaranya yaitu, pertama pada skenario pembelajaran terdapat ketidaksesuaian dengan buku panduan yaitu pada tema. Dalam buku panduan disebutkan tema binatang, tetapi pada skenario pembelajaran tema buah-buahan. Kedua, pada kegiatan relaksasi dalam skenario permainan terdapat kalimat yang kurang dipahami oleh guru. Terakhir pada format penilaian untuk anak terdapat kolom jumlah tanda ceklis dan silang yang kurang dimengerti oleh guru, seharusnya diperjelas lagi.

\section{3) Revisi Produk Skenario Pembelajaran Permainan Fun Outbound mencari harta karun}

Revisi produk ini dilakukan perbaikan sesuai hasil diskusi dan saran perbaikan yang diberikan pada saat validasi ahli. Revisi ini dilakukan setelah tahap expert judgment. Berikut ini pemaparan hasil revisi produk dari hasil uji validasi produk oleh validator ahli.

a. Revisi produk dari ahli materi Interaksi Sosial, berdasarkan masukan atau saran dari Drs. H. Sumardi M, Pd. Selaku ahli materi interaksi sosial, latar belakang buku dirubah menggunakan desain supaya terlihat menarik.

b. Revisi produk ahli desain Permainan, berdasarkan masukan atau saran dari Dr. H. Heri Yusuf Muslihin, M.Pd selaku ahli desain permainan, langkah-langkah dan cara-cara dalam permainan di jelaskan secara detail dan disertakan foto untuk ilustrasi dalam permainan. Kemudian jarak (spasi) dalam buku di rubah menjadi 1,15 supaya lebih nyaman dibaca oleh guru. Untuk ukuran buku dirubah menjadi B5 agar tidak terlalu besar dan tidak terlalu kecil.

c. Revisi produk ahli Pedagogik, berdasarkan masukan atau saran dari Tati, S.Pd. selaku ahli pedagogik, tema pada skenario pembelajaran disamakan dengan tema pada buku panduan yaitu menjadi tema Binatang. Kalimat pada kegiatan relaksasi yang semula "Anak diminta menjawab ketika temannya sedang bercerita" diperjelas menjadi "Anak diminta untuk menyimak atau menanggapi ketika temannya sedang bercerita" Kemudian pada format penilaian untuk anak kolom ceklis dan silang dibagian samping dihilangkan karena kolom jumlah sudah tersedia dibagian bawah.

\section{c. Evaluation and Reflektion}

Pada tahap ini, umumnya adalah tahap evaluasi dan refleksi dengan melakukan uji coba dan menilai produk yang dikembangkan untuk kemudian dievaluasi. Namun, pada penelitian ini tidak dilaksanakan uji coba karena adanya pandemi covid-19. Tahap evaluasi dilakukan setelah produk dilakukan validasi ahli saja.

Pada tahap refleksi, peneliti melakukan tinjauan terhadap data yang telah dikumpulkan terkait produk yang dikembangkan. Data tersebut berupa data yang dikumpulkan dari lapangan dan masukan dari para ahli. Peninjauan tersebut dilaksanakan sebagai tahap akhir penelitian untuk perbaikan dan revisi akhir produk sesuai data yang diperoleh serta dapat digunakan untuk memecahkan permasalahan yang menjadi fokus dalam penelitian.

\section{KESIMPULAN}

Berdasarkan hasil penelitian pengembangan bahan ajar permainan Fun Outbound mencari harta karun di taman kanak-kanak yang dilaksanakan di TK PGRI Lendrasari Kabupaten Ciamis, maka dapat diperoleh kesimpulan sebagai berikut:

1) Kebutuhan serta kekurangan yang belum tersedia dalam pengembangan bahan ajar dalam melaksanakan permainan Fun Outbound mencari harta karun adalah buku panduan untuk guru berupa skenario permainan. Berdasarkan hasil studi pendahuluan ke Sekolah ternyata guru masih berpacu pada satu bahan ajar yaitu dari kurikulum 2013 saja, dan dalam permainan Fun Outbound sudah pernah dilakukan di halaman sekolah, halaman kantor desa Sindangsari, dan pada saat anak-anak diajak jalan-jalan. Tetapi untuk permainan mencari harta karun belum pernah dilaksanakan. Kemudian masih terdapat satu sampai dua anak yang kemampuan interaksi sosialnya belum berkembang, itu dikarenakan anak tidak tertarik dengan permainan dan tidak mau tergabung bersama teman-teman lainnya. Sehingga anak fokus pada alat mainan yang ia sukai.

2) Desain permainan pada permainan Fun Outbound mencari harta karun yaitu berupa skenario permainan yang berpusat pada anak, sehingga anak terlibat langsung dalam proses pembelajaran. Melalui experiental learning (pengalaman secara langsung) anak sangat antusias dalam permainan mencari harta karun. Tahap perancangan skenario pembelajaran ini didasarkan pada metode (EDR) Educational 
Design Research model McKenney and Reeves. Pada tahap ini dihasilkan rancangan desain bahan ajar berupa buku panduan untuk guru tentang Permainan Fun Outbound mencari harta karun untuk memfasilitasi interaksi sosial anak usia dini. Setelah desain bahan ajar dirancang, dilakukan validasi produk oleh validator ahli untuk mengetahui kepraktisan dan keterpakaian produk yang akan di uji cobakan. Selanjutnya dilakukan revisi berdasarkan saran dari validator ahli, maka dihasilkan desain pembelajaran yang siap untuk di uji cobakan.

3) Guru memberikan tanggapan positif terhadap produk yang dikembangkan oleh peneliti. Guru memberikan pernyataan bahwa permainan ini bagus sekali. kebetulan di Sekolah tersebut belum pernah dilaksanakan, dan harapannya permainan ini dapat diuji cobakan karena anak-anak pasti senang karena permainan ini menantang, dilakukan secara berkelompok itu dapat melatih interaksi sosial, kerjasama, kebersamaan pada anak usia dini.

4) Bentuk desain pembelajaran ini ditekankan pada permainan Fun Outbound, karena pendidikan anak usia dini pada hakikatnya bermain. produk akhir yang dihasilkan berupa bahan ajar berupa panduan untuk guru tentang permainan Fun Outbound mencari harta karun untuk memfasilitasi interaksi sosial anak usia dini. Produk tersebut dapat digunakan pada anak kelompok B yang akan memasuki jenjang pendidikan sekolah dasar.

\section{SARAN}

Berdasarkan hasil penelitian dan pembahasan yang diperoleh dari penelitian ini, penulis mengemukakan beberapa saran sebagai berikut:

1) Proses penelitian dengan menggunakan metode (EDR) Educational Design Research ini perlu persiapan yang matang dan waktu yang cukup, agar mendapatkan hasil yang optimal.

2) Penelitian ini sebaiknya dikembangkan lagi pada tema pembelajaran yang lain.

3) Penelitian ini dapat menjadi bahan masukan dalam pengembangan bahan ajar permainan Fun Outbound mencari harta karun.

\section{DAFTAR PUSTAKA}

Abidin, Y. (2016). Desain Sistem Pembelajaran dalam Konteks
Kurikulum 2013. Bandung: PT Refika Aditama

Ancok, D. (2002). Outbound management training. Yogyakarta: Pusat Outbound H-READ UII.

Creswell, JW. (2017). Research Design: Pendekatan Kualitatif, Kuantitatif, dan Mixed. Jakarta: Pustaka Pelajar.

Febriana, AK. (2017). Pengaruh Kegiatan Outbound Terhadap Kemampuan Motorik Kasar Pada Anak Kelompok B di TK 02 Ngemplak Karangpandan Karanganyar Tahun Ajaran 2016/2017. Surakarta: Universitas Muhammadiyah Surakarta.

Imania, KAN. (2015). Hubungan Antara Pealatihan Outbound dengan Peningkatan Kinerja Karyawan. Jurnal Pendidikan Matematika. 2(4). 85-92.

McKenney,S \& Reaves, T.C (2012). Conducting Educational Design Research. New York: Routledge.

Rizal, AYC. (2017). Model Permainan Outbound untuk Meningkatkan Teamwork Anak Berkebutuhan Khusus di Kelas Tinggi di SD Luar Biasa PKK Provinsi Lampung. [Skripsi]. Lampung: Universitas Lampung.

Sahid, OSZ. (2017). Upaya Meningkatkan Keterampilan Sosial Anak Usia Dini melalui Permainan Tradisional di RA Assalam Wonorejo Kecamatan Gondangrejo Kabupaten Karanganyar Tahun Pelajaran 2016/2017. [Skripsi]. Surakarta: Institut Agama Islam Negeri Surakarta.

Sintia, N. (2018). Pengembangan Kemampuan Sosial Anak Melalui Outbound Umur 4-5 Tahun Di Tk As-Sallam 1 Sukarame Bandar Lampung. [Skripsi]. Lampung: Universitas Islam Negeri Raden Intan Lampung.

Sugiyono. (2015). Metode Penelitian Pendidikan. Bandung: Alfabeta.

Sujiono, YN. (2013). Konsep Dasar Pendidikan Anak Usia Dini. Jakarta: PT. Indeks.

Susanta, A. (2010). Outbound Profesional. Yogyakarta: CV Andi offset.

Wahjoedi, dkk. ( 2017). Model Pengembangan Pendidikan Karakter Pada Anak Usia Dini Berbasis Outbound di Kota Singaraja. 